\title{
First record of a reticulated toadfish, Arothron reticularis (Tetraodontiformes: Tetraodontidae), in Korea
}

\author{
Chung-Bae Kang ${ }^{1}$, Sang-Hwa Lee ${ }^{2}$, Tae-Sik Yu ${ }^{3}$, Hae-Rim Lee ${ }^{4}$ and Kyeong-Ho Han ${ }^{3^{*}}$ (D)
}

\begin{abstract}
A single specimen of Arothron reticularis (398 $\mathrm{mm}$ in total length), belonging to the family Tetraodontidae, was collected in the coastal waters off Hansan island using a set net in May 2019. The morphological characteristics of the specimen are as follows: large eyes and mouth, white spots on the body, and a white line surrounding the eyes in an annular shape. A result of maximum likelihood tree showed that A. reticularis is related to A. hispidus (93.6\%). We proposed the Korean name "Geu-murl-mu-nui-kkeo-kkeurl-bok," in accordance with the characteristics of the specimen.
\end{abstract}

Keywords: Tetraodontidae, New species, Arothron, Arothron reticularis, Reticulated toadfish

\section{Background}

The family Tetraodontidae (Order Tetraodontiformes) consists of 2 subfamilies, 26 genera, and 196 species worldwide (Nelson et al. 2016), of which 7 genera and 52 species occur in Japan (Nakabo and Yagishita 2013) and 5 genera and 31 species occur in Korea (MABIK 2020). Of the 196 species, the genus Arothron comprises 10 species that are present in Japan and 4 species in Korea (MABIK 2020).

The genus Arothron is distributed in the tropical regions of the Indo-Pacific, except for Arothron firmamentum (Temminck and Schlegel 1850), which is antitropical (Matsuura 2016). The reticulated toadfish, Arothron reticularis (Bloch and Schneider 1801), is distributed in the tropical waters of Okinawa, Taiwan, and the Indo-West Pacific (Masuda et al. 1984). The first report from the Red Sea was obtained in 1956, when Roux-Estève identified a specimen (197 mm in total length), which was from the island of Abulat (Abu Latt) in the Farasan Islands,

\footnotetext{
* Correspondence: aqua05@jnu.ac.kr

${ }^{3}$ Department of Fisheries Science, Chonnam National University, Yeosu 59626, South Korea

Full list of author information is available at the end of the article
}

southern Red Sea, as Tetraodon reticularis (Randall et al. 2012).

The genus Arothron is represented along the Korean coast by four species (Chyung 1977; Lee 1993): A. firmamentum, Arothron stellatus (Anonymous 1798), Arothron hispidus (Linnaeus 1758), and Arothron nigropunctatus (Bloch and Schneider, 1801). For the first time, $A$. reticularis, including morphological traits and mitochondrial DNA cytochrome c oxidase subunit I ( $m t$ $\mathrm{COI}$ ) sequences, was recorded based on single specimen collected from Korea.

\section{Materials and methods}

On May 9, 2019, a single reticulated pufferfish, $A$. reticularis, was captured from the coastal waters off Hansan Island using a set net (Fig. 1). The methods used for the fin ray counts and morphometric characters follow those of Han (1995). All morphometric measurements were measured to the nearest $0.1 \mathrm{~cm}$ using Vernier calipers. Soft $x$-ray microscopy (LISTEM, REX-525R, Korea) was used to count the number of vertebrae and fin rays.

For genetic analysis, the total genomic DNA was extracted from the prepared part of the tissue using the QIAamp DNA Micro Kit (Qiagen, Hilden, Germany),

(c) The Author(s). 2020 Open Access This article is licensed under a Creative Commons Attribution 4.0 International License, which permits use, sharing, adaptation, distribution and reproduction in any medium or format, as long as you give appropriate credit to the original author(s) and the source, provide a link to the Creative Commons licence, and indicate if changes were made. The images or other third party material in this article are included in the article's Creative Commons licence, unless indicated otherwise in a credit line to the material. If material is not included in the article's Creative Commons licence and your intended use is not permitted by statutory regulation or exceeds the permitted use, you will need to obtain permission directly from the copyright holder. To view a copy of this licence, visit http://creativecommons.org/licenses/by/4.0/ 


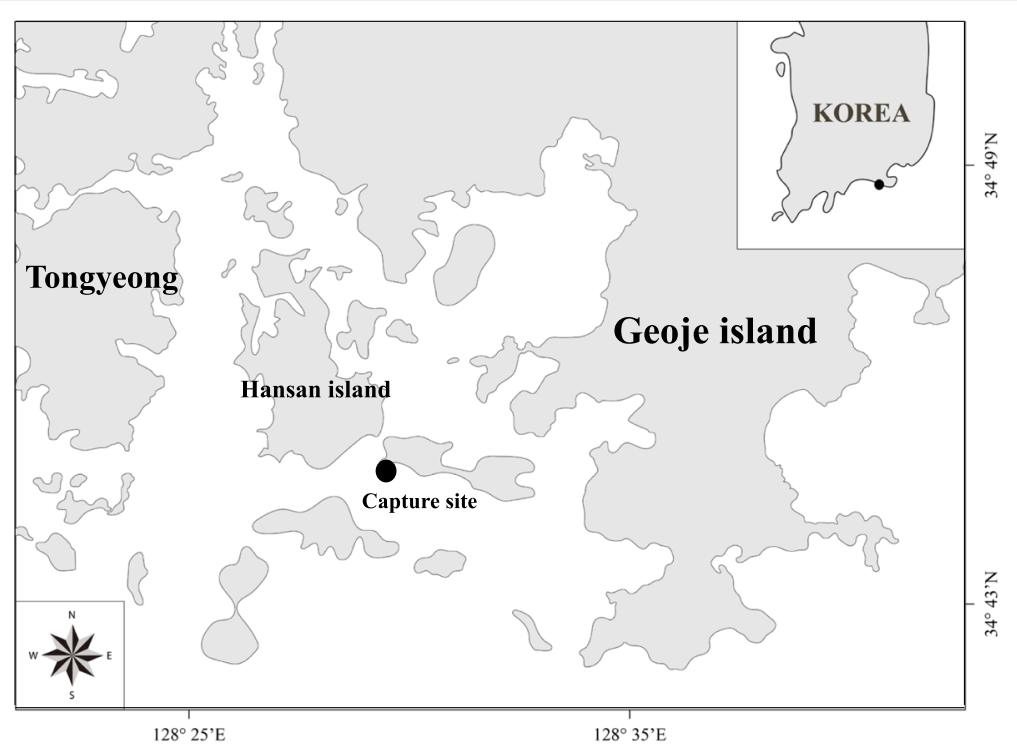

Fig. 1 Map showing the capture site of Arothron reticularis in the coastal waters off Hansan Island

following the manufacturer's instructions. The polymerase chain reaction (PCR) amplification was performed using the 2X TOPsimple ${ }^{\mathrm{TM}}$ PreMIX (aliquot) (Enzynomics, Daejeon, Korea) with the universal mitochondrial COI primer set, LCO1490 forward primer (5'-GGT CAA ATC ATA AAG ATA TTG G-3') and HCO2198 reverse primer $\left(5^{\prime}\right.$-TAA ACT TCA GGG TGA CCA AAA AAT CA-3') (Folmer et al. 1994). The amplified PCR product was sequenced using the Applied Biosystems 3730xl DNA Analyzer (ThermoFisher, Foster City, CA, USA). The obtained $m t$ COI sequence ( $658 \mathrm{bp}$ ) was compared with 16 Tetraodontiformes $m t \mathrm{COI}$ sequences (14 Tetraodontidae species and 2 Ostraciidae species [as an outgroup]) retrieved from GenBank (Appendix 1). In total, 17 sequences were aligned using MAFFT v.7 (Katoh and Standley 2013) in Geneious v.9 (Biomatters Ltd.). The phylogenetic tree was reconstructed using the maximum likelihood (ML) method based on the GTR+ G+I model and 10,000 bootstrap replications in the raxmlGUI 2.0 program (Edler et al. 2020).

\section{Results and discussion}

Family Tetraodontidae Bonaparte, 1831

Genus Arothron Müller, 1841

Tetraodon Linnaeus, 1758: 333 (type species: Tetraodon lineatus Linnaeus)

Arothron reticularis (Bloch and Schneider 1801)

(New Korean name: Geu-murl-mu-nui-kkeo-kkeurlbok) (Fig. 2)

Tetrodon reticularis Bloch \& in Schneider, 1801: 506 (type locality: Malabar coast, India)

Arothron reticularis: Matsuura et al. 1984: 364 (Japan); Nakabo 2000: 1429 (Japan); Allen and Adrim, 2003: 65

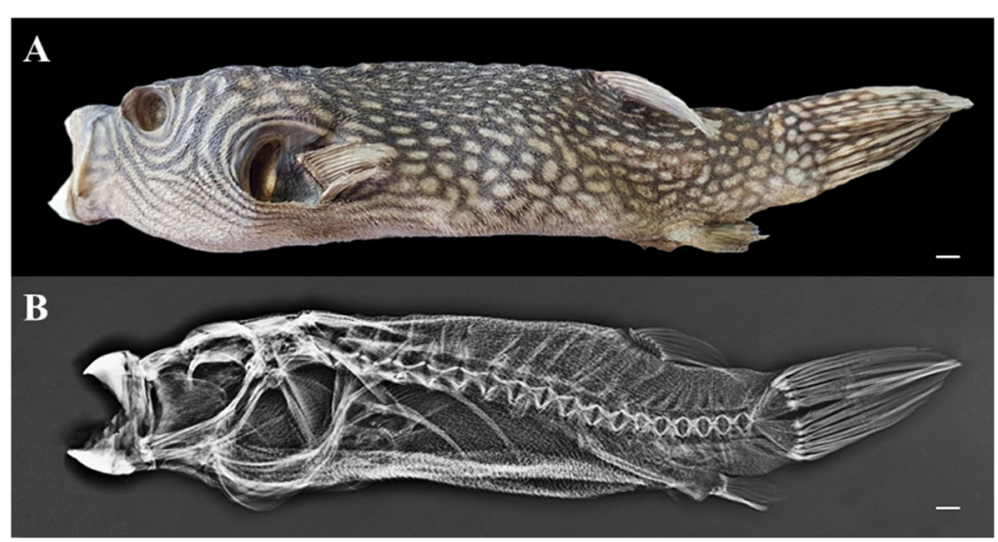

Fig. 2 Arothron reticularis (MABIK PI00049568). a Lateral view. b X-ray radiograph (scale bars indicate $10 \mathrm{~mm}$ ) 
(Indonesia); Veeruraj et al., 2011: 4 (India); Sonoyama et al., 2020: 130 (Japan).

\section{Materials examined}

Arothron reticularis (MABIK PI00049568) $330 \mathrm{~mm}$ standard length (SL) (398 mm total length [TL]) was collected in the coastal waters off Hansan Island, Gyeongsangnam-do, Republic of Korea, using a set net on May 9, 2019 (Fig. 3).

\section{Description}

The morphological trait measurements for the present specimen are shown in Table 1 . The measurements expressed as a percentage of the SL include the following: body depth, 26.1; head length, 39.4; predorsal length, 79.7; prepectoral length, 44.1; preanal length, 85.8; length of dorsal fin, 17.0; length of pectoral fin, 12.7; length of anal fin, 13.6; caudal peduncle depth, 14.5; preanus length, 80.2; dorso-caudal peduncle length, 18.2; and ventro-caudal length, 17.3. The measurements expressed as a percentage of the head length include the following: nasal length, 35; snout length, 38; eye diameter, 27; and interorbital width, 54. The fin ray counts are as follows: dorsal fin rays, 10; pectoral fin rays, 10; anal fin rays, 10; caudal fin rays, 11; and vertebrae, 18 $(10+8)$.

The nostril has two fleshy flaps, formed by the bifurcation of a single base (Fig. 4). The body is elongated and covered with prickles, except for the regions around the mouth and caudal peduncle. The eyes are notably large, broad, and flat. The mouth is large with four teeth,

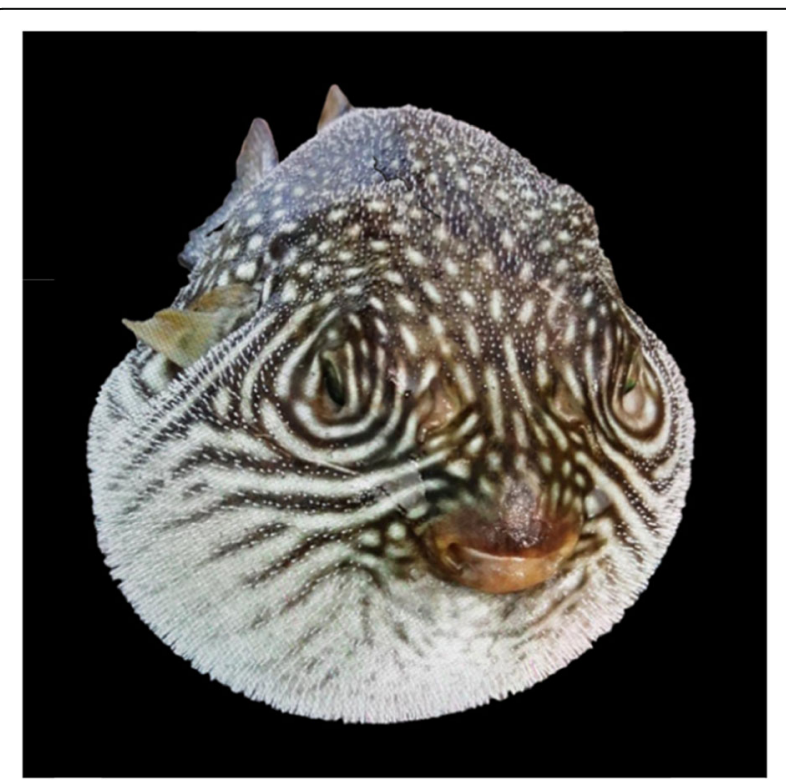

Fig. 3 Frontal view of the fresh Arothron reticularis specimen
Table 1 Comparison between the morphological traits of the genus Arothron in this study and previous studies

\begin{tabular}{|c|c|c|c|c|}
\hline \multirow{2}{*}{$\begin{array}{l}\text { Morphological } \\
\text { characteristics }\end{array}$} & Present & Sujatha and & \multicolumn{2}{|l|}{ Han (1995) } \\
\hline & \multicolumn{2}{|c|}{ A. reticularis } & A. & A. \\
\hline $\begin{array}{l}\text { Standard length } \\
\text { (SL, mm) }\end{array}$ & 330 & $264-478$ & $269-350$ & $391-410$ \\
\hline $\begin{array}{l}\text { Total length as } \\
\% \text { SL }\end{array}$ & 121 & $118-125$ & - & - \\
\hline $\begin{array}{l}\% \text { in body } \\
\text { depth }\end{array}$ & 32 & $34-41$ & $36.0 \pm 4.6$ & $\begin{array}{l}48.7 \pm \\
2.3\end{array}$ \\
\hline $\begin{array}{l}\% \text { in head } \\
\text { length }\end{array}$ & 39 & $33-36$ & $29.5 \pm 0.9$ & $\begin{array}{l}30.8 \pm \\
1.0\end{array}$ \\
\hline $\begin{array}{l}\% \text { in predorsal } \\
\text { length }\end{array}$ & 80 & $73-81$ & $69.9 \pm 1.2$ & $\begin{array}{l}66.7 \pm \\
1.3\end{array}$ \\
\hline $\begin{array}{l}\% \text { in } \\
\text { prepectoral } \\
\text { length }\end{array}$ & 44 & $34--40$ & - & - \\
\hline $\begin{array}{l}\% \text { in preanal } \\
\text { length }\end{array}$ & 86 & $72-82$ & $75.0 \pm 2.3$ & $\begin{array}{l}70.5 \pm \\
1.3\end{array}$ \\
\hline $\begin{array}{l}\% \text { in length of } \\
\text { dorsal fin }\end{array}$ & 17 & $16-19$ & $20.3 \pm 1.9$ & $\begin{array}{l}15.4 \pm \\
1.1\end{array}$ \\
\hline $\begin{array}{l}\% \text { in length of } \\
\text { pectoral fin }\end{array}$ & 13 & $13-16$ & $14.6 \pm 1.1$ & $\begin{array}{l}11.5 \pm \\
0.7\end{array}$ \\
\hline $\begin{array}{l}\% \text { in length of } \\
\text { anal fin }\end{array}$ & 14 & $15-17$ & - & - \\
\hline $\begin{array}{l}\text { \% in caudal } \\
\text { peduncle } \\
\text { depth }\end{array}$ & 15 & $21-27$ & $12.2 \pm 1.8$ & $\begin{array}{l}14.1 \pm \\
0.7\end{array}$ \\
\hline $\begin{array}{l}\% \text { in preanus } \\
\text { length }\end{array}$ & 80 & - & - & - \\
\hline $\begin{array}{l}\text { \% in dorso- } \\
\text { caudal } \\
\text { peduncle } \\
\text { length }\end{array}$ & 18 & - & $16.2 \pm 0.7$ & $\begin{array}{l}20.5 \pm \\
0.1\end{array}$ \\
\hline $\begin{array}{l}\% \text { in ventro- } \\
\text { caudal } \\
\text { peduncle } \\
\text { length }\end{array}$ & 17 & - & $18.9 \pm 1.2$ & $\begin{array}{l}21.5 \pm \\
1.1\end{array}$ \\
\hline \multicolumn{5}{|l|}{$\begin{array}{l}\% \text { in head } \\
\text { length }\end{array}$} \\
\hline $\begin{array}{l}\% \text { in nasal } \\
\text { length }\end{array}$ & 35 & - & - & - \\
\hline $\begin{array}{l}\% \text { in snout } \\
\text { length }\end{array}$ & 38 & $38-44$ & - & - \\
\hline $\begin{array}{l}\% \text { in eye } \\
\text { diameter }\end{array}$ & 27 & $30-36$ & - & - \\
\hline $\begin{array}{l}\% \text { in } \\
\text { interorbital } \\
\text { width }\end{array}$ & 54 & $51-62$ & - & - \\
\hline \multicolumn{5}{|l|}{ Counts } \\
\hline Dorsal fin rays & 10 & $10-11$ & 14 & $11-12$ \\
\hline Pectoral fin rays & 18 & $17-18$ & $13-14$ & 11 \\
\hline Anal fin rays & 10 & $10-11$ & $15-16$ & $18-19$ \\
\hline Caudal fin rays & 11 & $10-11$ & - & - \\
\hline Vertebrae & 18 & - & 20 & 18 \\
\hline
\end{tabular}




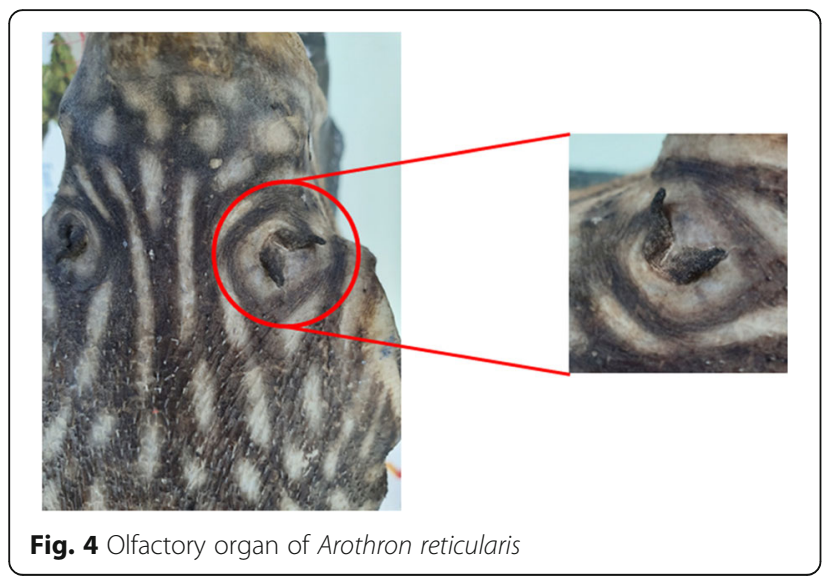

and the dentary is protruded further than the premaxillary. The lateral line is indistinct. The gill slit is large.

\section{Coloration of the specimen}

When fresh, there were white lines on the body that curved from around the eyes and then across the abdomen. There were no ventral extensions of the dark body color into the pale ventral part of the head or body. White spots were present from the dorsal of the head to the caudal fin. After preservation, the ventral surface turned beige, and the body turned greenish brown. There are white spots on the body and a white line surrounds the eyes in an annular shape (Fig. 3)

\section{Distribution}

The distribution occurred in the Southern Sea of Korea (present study) and Indo-West Pacific Ocean, including the South China Sea and Ryukyu Islands (Veeruraj et al. 2011).

\section{Comparison with type species}

The difference between $A$. reticularis and the type species (Tetraodon lineatus) are as follows: T. lineatus has 2 3 dorsal spines, 9 10 dorsal soft rays, 2 anal spines, and 7 8 anal soft rays (Fishbase 2020). There was no difference in the distribution of prickles; however, the white spots and white lines around the eyes were absent in T. lineatus.

\section{Remarks}

Although the measurements were taken in a dry state, the morphological traits of the present specimen are similar to those of Sujatha and Padmavathi (2015). There were differences in morphometric traits between $A$. stellatus and A. firmamentum (Table 1).

The morphological classification keys of the genus Arothron fish are the spots and lines around the eyes, ventral part, and caudal fin. A. reticularis morphologically resembles the genus Arothron fish, but differs in the distribution of prickles (prickles absent on the snout and

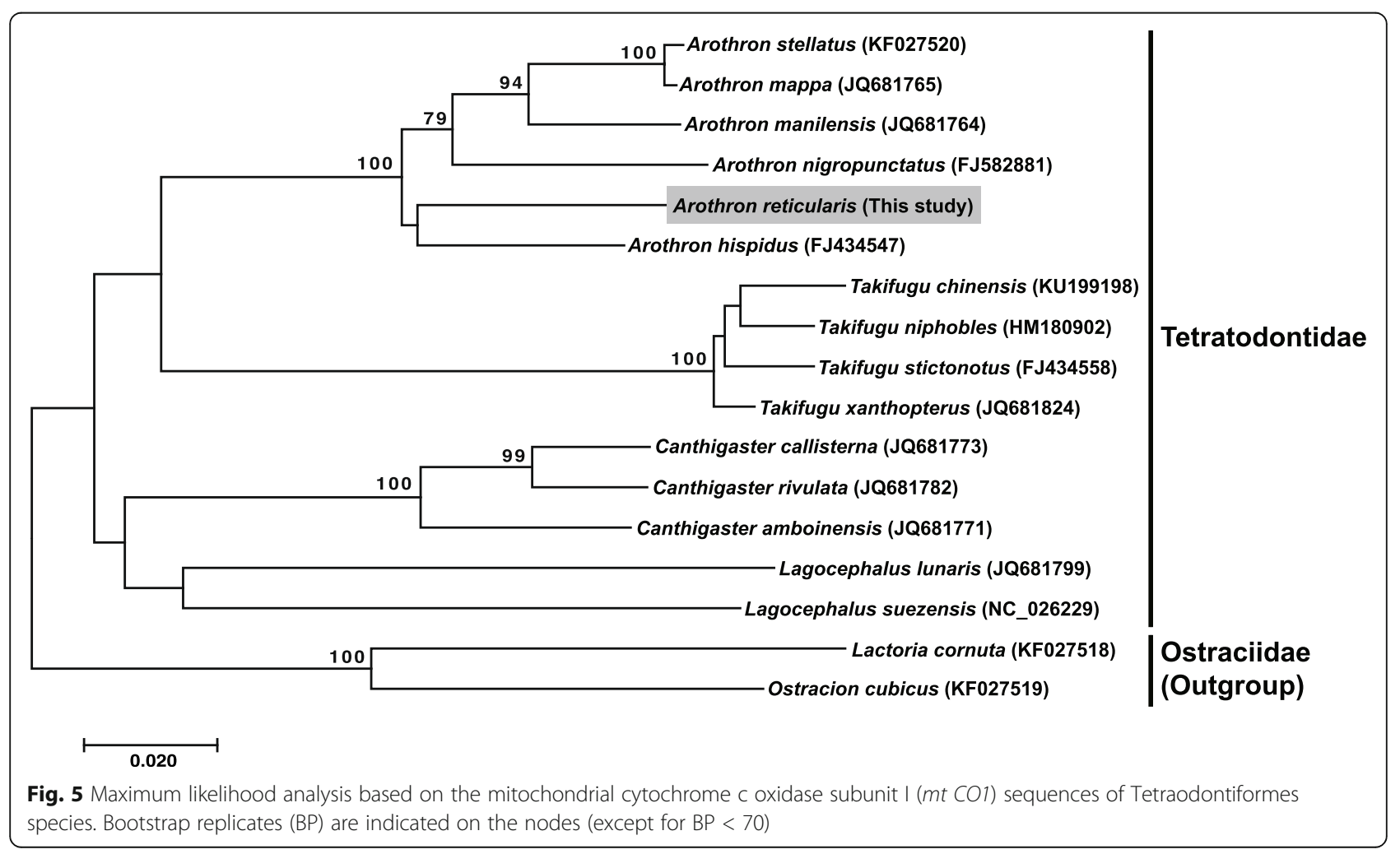


at least the posterior half of the caudal peduncle in $A$. hispidus), white line around the head (white spots around the head in A. hispidus) (Randall et al. 2012), white spots scattered around the caudal fin (caudal fin has no white spots of $A$. carduus and A. manilensis) (Nakabo 2000), and discontinuous stripes on the body (continuous stripes on the body of A. multilineatus) (Matsuura 2016). This species has a reticulate pattern on the body. In accordance with the characteristics, a new Korean name was proposed for this species "Geu-murlmu-nui-kkeo-kkeurl-bok."

In this study, a partial gene sequence of the $m t$ COI (658 bp) of $A$. reticularis was obtained for the first time. Using this sequence, we created an $m t$ COI dataset, including 16 Tetraodontiformes $m t C O I$ sequences from GenBank, and analyzed the genetic distance of $A$. reticularis using Kimura-2-Parameter method. Neighborjoining tree showed that $A$. reticularis belongs to the genus Arothron (family Tetraodontidae) and is related to A. hispidus (similarity 93.6\%) (Fig. 5).

\section{Conclusions}

One specimen of reticulated toadfish was collected in the coastal waters off Hansan Island on May 9, 2019. The specimen was identified as Arothron reticularis, based on morphological traits and the first record of species in Korea.

\section{Supplementary Information}

The online version contains supplementary material available at https://doi. org/10.1186/s41240-020-00176-5.

Additional file 1: Appendix 1. List of 17 species used in the phylogenetic analysis of this study.

\section{Acknowledgements}

This work was supported by the Efficient Securement of Marine Bioresources and Taxonomic Research (2020 M00100), funded by the National Marine Biodiversity Institute of Korea (MABIK). We would like to thank the head of Bongam Village, Hansan Island, for providing the sample.

\section{Authors' contributions}

CBK and TSY wrote the manuscript. SHL and HRL carried out the molecular genetic experiments. $\mathrm{KHH}$ designed the study and finalized the manuscript. All authors read and approved the final manuscript.

\section{Ethics approval and consent to participate}

Not applicable.

\section{Consent for publication}

Not applicable.

\section{Competing interests}

The authors declare that they have no competing interests.

\section{Author details}

'Department of Exhibition and Education, Marine Biodiversity Institute of Korea, Seochen 33662, South Korea. ${ }^{2}$ Department of Taxonomy and Systematics, Marine Biodiversity Institute of Korea, Seochen 33662, South Korea. ${ }^{3}$ Department of Fisheries Science, Chonnam National University, Yeosu
59626, South Korea. ${ }^{4}$ Department of Animal Welfare, National Institute of Ecology, Seochen 33657, South Korea.

Received: 22 July 2020 Accepted: 27 November 2020

Published online: 21 December 2020

References

Chyung MK. The fishes of Korea. Seoul: Ilji Publishing Co; 1977

Edler D, Klein J, Antonelli A, Silverstro D. raxmIGUI 2.0: a graphical interface and toolkit for phylogenetic analyses using RAxML. bioRxiv. 2020. https://doi.org/ 10.1111/2041-210X.13512

Fishbase. Sweden, Stockholm 2020. http://fishbase.org. Accessed 29 May 2020.

Folmer O, Black M, Goeh W, Lutz R, Vrijenhoek R. DNA primers for amplification of mitochondrial cytochromec oxidase subunit I from divers metazoan invertebrates. Mol Mar Biol Biotechnol. 1994:3:294-9.

Han KH. Morphology, osteology and phylogeny of the fishes of the family Tetraodontidae (Teleostei: Tetraodontiformes). Busan: PhD thesis: Pukyong National University, Department of Marine Biology; 1995.

Katoh K, Standley DM. MAFFT multiple sequence alignment software version 7: improvements in performance and usability. Mol Biol Evol. 2013;30:772-80.

Lee WO. New records of six species of the Tetraodontidae (Pisces: Tetraodontiforems) from Korea. Korean J Ichthyol. 1993;5:165-76.

MABIK. National list of marine species. Seocheon: Namu Press; 2020.

Masuda H, Amaoka K, Araga C, Uyeno T, Yoshino T. The fishes of the Japanese archipelago 2nd ed. Tokyo: Tokai University Press; 1984.

Matsuura K. A new pufferfish, Arothron multilineatus (Actinopterygii: Tetraodontiformes: Tetraodontidae), from the Indo-West Pacific. Ichthyol Res. 2016. https://doi.org/10.1007/s10228-016-0517-8.

Nakabo T. Fishes of Japan with pictorial keys to the species. 2nd ed. Tokyo: Tokai University Press; 2000.

Nakabo T, Yagishita N. Tetraodontidae: fishes of Japan with pictorial keys to the species. 3rd ed. Tokyo: Tokai University Press; 2013.

Nelson JS, Grande TC, Wilson MVH. Fishes of the world. 5th ed. New York: John Wiley \& Sons; 2016.

Randall JE, Bogorodsky SV, Rose JM. Color variation of the puffer Arothron hispidus (Linnaeus) and comparison with A. reticularis (Bloch \& Schneider). Aqua International Journal of Ichthyology. 2012:18:41-54.

Sujatha K, Padmavathi P. Taxonomy of puffer fish (Pisces: Tetraodontidae) represented in the catches of Visakhapatnam, central eastern coast of India. J Mar Biol Ass India. 2015. https://doi.org/10.6024/jmbai.2015.57.2.1798-14.

Veeruraj A, Arumugam M, Ajithkumar T, Balasubramanian T. Distribution of Tetraodontiformes (Family: Tetraodontidae) along the Parangipettai Coast, Southeast coast of India. Zootaxa. 2011. https://doi.org/10.11646/zootaxa. 3015.1.1.

\section{Publisher's Note}

Springer Nature remains neutral with regard to jurisdictional claims in published maps and institutional affiliations.

Ready to submit your research? Choose BMC and benefit from

- fast, convenient online submission

- thorough peer review by experienced researchers in your field

- rapid publication on acceptance

- support for research data, including large and complex data types

- gold Open Access which fosters wider collaboration and increased citations

- maximum visibility for your research: over $100 \mathrm{M}$ website views per year

At $\mathrm{BMC}$, research is always in progress.

Learn more biomedcentral.com/submission 